MAKÜ FEBED

ISSN Online: 1309-2243

http://dergipark.ulakbim.gov.tr/makufebed

Mehmet Akif Ersoy Üniversitesi Fen Bilimleri Enstitüsü Dergisi 7(1): 67-74 (2016)

The Journal of Graduate School of Natural and Applied Sciences of Mehmet Akif Ersoy University 7(1): 67-74 (2016)

Derleme Makale / Review Paper

\title{
Hava Kirleticilerin Bitkilere Etkileri
}

\author{
Cengiz YÜCEDAĞ ${ }^{1}$, Latif Gürkan KAYA ${ }^{1 *}$ \\ Mehmet Akif Ersoy Üniversitesi Mühendislik Mimarlık Fakültesi, Burdur \\ Geliş Tarihi (Received): 12.02.2016, Kabul Tarihi (Accepted): 30.03.2016 \\ $\square$ Sorumlu Yazar (Corresponding author)*: Igkaya@gmail.com \\ (6) +902482132703 运 +902482132704
}

$\overline{\text { öz }}$

Dünyada hızlı gelişen kentleşme ve endüstrileşme ile bilinçsiz tarımsal uygulamalar sonucunda ciddi hava kirliliği problemleri ortaya çıkmıştır. Çeşitli endüstriyel kaynaklardan atmosfere verilen hava kirleticiler, başta insanlar olmak üzere bitkiler ve hayvanlar üzerinde önemli zararlara neden olmaktadır. Dolayısıyla bu çalışmada, başlıca hava kirleticilerine yer verilmiş ve bunların bitkiler üzerine etkileri incelenmiştir.

Anahtar Kelimeler: Hava kirliliği, hava kirletici, bitki, kentleşme, endüstri

\section{Impacts of Air Pollutants to Plants}

\begin{abstract} and their impacts on the plants have been investigated.

Keywords: Air pollution, air pollutant, plant, urbanization, industry

\section{GíRiş}

Dünyada hava kirletici emisyonlarında 2030 yılına kadar beş katına kadar bir artış beklenmektedir. Türkiye'de hava kirliliği özellikle 1950 'lerden sonra hızlı nüfus artışı, hızlı kentleşme, endüstrileşme sonucu yoğun enerji kullanımı nedeniyle bir halk sağlığı sorunu olmaya başlamıştır (Bayram, 2005). 1970'li yıllara gelindiğinde başta Ankara olmak üzere büyük kentlerin hemen tamamında ağır bir hava kirliliği yaşanmış ve özellikle Muğla'da bulunan Yatağan ve Yeniköy termik santralleri hava kirliliği nedeniyle gündeme gelmiştir.
\end{abstract}

In the World, the rapid development of urbanization and industrialization with unconscious agricultural practices have emerged serious air pollution problems. Air pollutants into the atmosphere from various industrial sources have caused important damages on human, plants and animals. Therefore, in the study, the major air pollutants
Hava kirliliği; doğal olaylar veya insan faaliyetleri sonucunda oluşan, atmosferin doğal bileşimini değiştiren, yoğunluğu ve atmosferde kaldıkları süreye bağlı olarak insan sağlığına, bitki ve hayvan hayatına zararlı olan gaz ve tanecikler olarak tanımlanabilmektedir (Eğri, 1997). Topoğrafik ve meteorolojik özelliklerin dikkate alınmadığı yanlış kentleşme, uygunsuz ve yersiz yakma teknikleri, yeşil alanların azalması, motorlu araç sayısındaki artış, atıkların yetersiz atılımı hava kirliliğini daha da artırmıştır (Bayram, 2005). ferde bulundukları ortama değil, o ortamdan belki de
Kaynaklardan yayılan hava kirleticiler, sadece atmos- 
kilometrelerce uzaklıkta etkili olabilmektedir. Global ölçekte $\mathrm{CO}_{2}$ artışının yol açtığı sera etkisinin ve ozon tabakasının delinmesi gibi etkilerin atmosferde önemli ölçüde klimatolojik değişmelere yol açtığı belirlenmiştir. Hava kirliliğinin neden olduğu asit yağmurlarının ormanları tahrip ettiği ve gölleri asitleştirerek ekolojik dengenin bozulmasına yol açtığı tespit edilmiştir. $\mathbf{S O}_{2}$, $\mathrm{CO}, \mathrm{NO}_{x}$, partikül gibi hava kirleticilerin ise insan sağlığı, bitkiler, yapı ve malzemeler üzerinde olumsuz etkiler meydana getirdiği bilinmektedir (Amil, 2005).

Hava kirliliği atmosfer bileşimini değiştirerek sıcaklık ve yağış modellerini değiştirmekte, su ve toprağın kirlenmesine neden olmaktadır. Atmosfer bileşimi, gerek açık gerekse kapalı alanlarda (sera ve depo) bitki yetiştiriciliğini ve muhafazasını etkileyen önemli bir faktördür (Dursun, 1998). Son yıllarda atmosfer bileşimi bitki yetiştiriciliğini sınırlayan önemli bir çevre faktörü olarak değerlendirilmektedir. Dünya üzerinde hava kirliliği ağaçlara, çim bitkilerine, süs bitkilerine zarar vermekte ve tarım ürünlerinde verim kayıplarına neden olmaktadır (Seyyednejad ve Koochak, 2011). Yine, özellikle Türkiye'nin güneyinde kalan Muğla'daki termik santraller ve İskenderun'daki sanayi bölgesinin çevresindeki orman alanlarında yaprak/ibre kayıp oranlarının yüksek olmasının nedeni hava kirliliğidir (Tolunay ve ark., 2013).

Hava kirliliği kontrolünün kanuni süreçlere girmesiyle, dünyanın bir çok ülkesinde yerel ve Dünya Sağlık Örgütünün (WHO) belirlediği kirletici sınır değerleri ve emisyon kriterleri kullanılmaktadır (Bayram ve ark., 2006). Öte yandan, ülkemizde hava kirliliği 06.06.2008 tarihli 26898 sayılı Resmi Gazete'de yayımlanan Hava Kalitesi Değerlendirme ve Yönetimi Yönetmeliği çerçevesinde kontrol altına alınmaya çalışılmıştır (URL1, 2015). Bu çalışmada başlıca hava kirleticilerine yer verilmiş ve bunların bitkilere etkisi üzerinde durulmuştur.

\section{BAŞLICA HAVA KİRLETICILERI}

Hava kirleticileri atmosfere erişim yollarına bağlı olarak birincil ve ikincil kirleticiler olarak sınıflandırılmaktadır (Çınar, 2008).

\section{Birincil (primer) kirleticiler}

Birincil kirleticiler atmosfere kaynaktan direkt gönderilen ve bir değişime uğramayan kirleticilerdir. Bunlar; kükürtdioksit $\left(\mathrm{SO}_{2}\right)$, hidrojensülfür $\left(\mathrm{H}_{2} \mathrm{~S}\right), \quad$ azotmonoksit (NO), azotdioksit $\left(\mathrm{NO}_{2}\right)$, karbonmonoksit $(\mathrm{CO})$, karbondioksit $\left(\mathrm{CO}_{2}\right)$ ve partiküllerdir (Demirel, 2010).

\section{İkincil (sekonder) kirleticiler}

İkincil kirleticiler kaynaktan çıktıktan sonra atmosferde bulunan diğer maddelerle reaksiyona girip bu reaksiyonlar sonucu ortaya çıkan bileşikleri ifade eder. Bunlar; kükürttrioksit $\left(\mathrm{SO}_{3}\right)$, sülfürik asit $\left(\mathrm{H}_{2} \mathrm{SO}_{4}\right)$, ozon $\left(\mathrm{O}_{3}\right)$, aldehit ve ketonlar, peroksi asetil nitrat (PAN) ve ağır. Oysa bunların oluşumuna zemin oluşturan hidrokarbonlar ve NO birincil kirletici grubundadır. Çok çeşitli kaynaklardan salınmalarına rağmen diğer kirleticiler gibi çoğunluğu birincil kaynaklardan salınan antropojenik kökenli olup diğer bir kısmında atmosferde maruz kaldıkları değişimler sonucu oluşan ikincil aerosollardır (Çınar, 2008).

\section{HAVA KIRLETICILERIN BITKILERE ETKILERI}

Çeşitli endüstriyel kaynaklardan atmosfere verilen zararlı gaz ve maddeler, dünyanın değişik ülkelerinde başta insanlar olmak üzere bitkiler ve hayvanlar üzerinde önemli zararlar yapmaktadır. Hava kirleticilerinin bitkiler üzerindeki zehirli etkisi, kirletici türü ve konsantrasyonuna, bitki türü ve gelişme dönemine, ışık ve sıcaklık gibi çevresel faktörlere göre değişmektedir (Elkoca, 2002).

Havada kirlilik yaratan maddeler bitki yapraklarının yüzeyine temas ile yapraktaki solunum gözeneklerinin kapakçıklarını tıkayarak, solunum gözeneklerinden içeri girip karbondioksit özümlemesine katılarak olumsuz etkiler yapmaktadırlar (Kantarcı, 1995). Hava kirliliği, yapraklarda nekrozlara ve klorofil miktarında azalmalara sebep olmak suretiyle, fotosentetik aktivitenin gerilemesine ve buna bağlı olarak çap gelişimi, boy ve yaprak alanı gibi çeşitli büyüme parametrelerinin olumsuz yönde etkilenmesine neden olmaktadır (Pandey ve Agrawal, 1994). Hava kirliliği, bitki fizyolojisi veya biyokimyasal aşamalar üzerine etkili olduğu gibi, büyüme veya verimde önemli kayıplara ve besin kalitesinde değişikliklere neden olabilir (Ashmore ve Marshall, 1999). Kuzey Amerika'da (Heck ve ark., 1988) ve Güney Asya'da (Wahid ve ark., 1995) yapılan kapsamlı çalışmalar, ortam hava kirliliğinin önemli ürünlerde ciddi verim kaybına yol açtığını göstermiştir.

Hava kirliliğinin ağaç gelişimine olumsuz etkileri neticesinde, kirliliğe hassas tür ve genotiplerin rekabet güçlerinde önemli azalmalar meydana gelmektedir (Karnosky ve ark., 1992). Hava kirliliği Norveç ladini ve Avrupa kayınında bir takım kalıcı genetik farklılıklara sebep olmuş ve ayrıca çalışma alanlarında göknar ağacı (Abies sp.) sayısında önemli miktarda azalma görülmüştür. Ayrıca, çiçeklenmede bozulma dolayısıyla üreme-etkin popülasyon boyutunda azalmaya neden olmuştur (Longauer ve ark., 2004). 
İmir'in kuzey kısmında yer alan endüstri tesislerinden kaynaklı hava kirliliği kızılçam ve karaçam ağaçlarının yıllık halkalarında azalmalara neden olmuştur (Tolunay, 2003). Hava kirliliğine maruz kalan Eucalyptus camaldulensis ağacında yüksek miktarda çözünür karbonhidrat ve prolin içeriği saptanmıştır. Yani kirlenmiş yapraklarda prolin seviyesi artmıştır (Seyyednejad ve Koochak, 2011)

Yeniköy termik santrali çevresinde bulunan kızılçam ağaçlarının iğne yapraklarında hava kirliliği kaynaklı reçine kanal genişlemesi ve epidermis/hipodermis tabakalarının incelmesi saptanmıştır (Nuhoğlu, 2005) Aynı zamanda, endodermis tabakası ve iletim doku hücrelerinin deforme olduğu, hücre içi materyallerinin kaybolduğu, 2-3 yaşlı iğne yaprakların çok erken döküldüğü belirlenmiştir. Linyit kömürle çalışan bir termik santral çevresinde oluşan hava kirliliği ise bitkilerin fotosentetik pigmentlerinde azalmaya ve aynı zamanda Azadirachta indica A.Juss ağaç türünde rubisco enziminin büyük oranda bozulmasına neden olmuştur (Govindaraju ve ark., 2010).

Araç kaynaklı emisyon gazlarının meydana getirdiği ağır metal kirliliği üzerine yapılan bir çalışmada, çevre yoluna $100 \mathrm{~m}$ uzaklıktan toplanan tohumlar yüksek oranda çimlenirken, çevre yoluna yakın yerlerden (0$30 \mathrm{~m}$ arasında bir uzaklıktan) toplanan tohumların ise ön işlem uygulanmasına rağmen uzun süreli denemelerde bile çimlenmedikleri görülmüştür (Ganatas ve ark., 2011). Hava kirliliğinin bazı Akdeniz orman ağacı türleri üzerindeki etkileri Tablo 1'de verilmiştir.

Tablo 1. Bazı Akdeniz orman ağacı türlerine hava kirliliğinin etkileri (Bussotti ve Ferretti, 1998)

\begin{tabular}{|c|c|c|c|}
\hline Tür & Deney Tipi & Kirletici/Konsantrasyon/Zaman & $\begin{array}{l}\text { Etkiler } \\
\end{array}$ \\
\hline \multirow{7}{*}{$\begin{array}{l}\text { Pinus } \\
\text { halepensis }\end{array}$} & $\begin{array}{l}\text { Alan gözlemleri ve kontrollü } \\
\text { ortamda ( } 5 \text { yıllık fidanlar) }\end{array}$ & $\begin{array}{l}\text { Hem alanda }(<210 \mathrm{ppb}) \text { hem de kontrollü koşull- } \\
\text { arda ( } 2 \text { ay boyunca günde } 7 \text { saat ortalama } 70 \\
\text { ppb) ozon uygulaması }\end{array}$ & Görünür semptomlar (klorotik benekler) \\
\hline & $\begin{array}{l}\text { Fumigasyon odalarında ( } 2 \text { yıllık } \\
\text { fidanlar) }\end{array}$ & $\begin{array}{l}\text { Büyüme mevsimi boyunca episodik (5 güne } \\
\text { kadar) ozona maruz kalma (<120 ppb) }\end{array}$ & $\begin{array}{l}\text { Görünür semptomlar (klorotik benekler); } \\
\text { endodermiste nişasta birikimi; kalburlu } \\
\text { damar hücrelerinin büzülmesi }\end{array}$ \\
\hline & $\begin{array}{l}\text { Kontrollü ortamda } \quad(18 \text { aylık } \\
\text { fidanlar) }\end{array}$ & $\begin{array}{l}\text { 2-16 günlük süre boyunca ozon (150-600 ppb) } \\
\text { uygulaması }\end{array}$ & $\begin{array}{l}\text { - Düşük ozonda miristik ve palmitik } \\
\text { asitte artış, kloroplast boyu ve } \\
\text { stroma kararmasında azalma } \\
\text { - Yüksek ozonda linolenik asitte } \\
\text { azalma, kloroplast membranlarının } \\
\text { bozulması }\end{array}$ \\
\hline & $\begin{array}{l}\text { Üstü açık ortamda (1-3 yıllık } \\
\text { fidanlar) }\end{array}$ & $\begin{array}{l}3 \text { yıllık süre boyunca yaz işlemlerinde (haftada } 5 \\
\text { gün günde } 7 \text { saat) ozon (filtreli ve filtrelenmemiş } \\
\text { hava; ortam havası }+40 \text { ppb ozon) uygulaması }\end{array}$ & $\begin{array}{l}\text { Ozon uygulamasının ikinci yılında } \\
\text { görünür belirtiler; net fotosentez, sto- } \\
\text { matal iletkenlik, klorofil, } N \text { ve P'da } \\
\text { azalma }\end{array}$ \\
\hline & 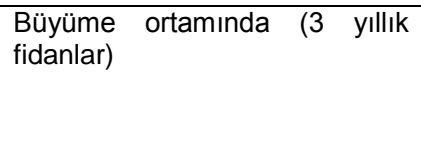 & $\begin{array}{l}2 \text { aylık süre boyunca ozon (100 ppb) ve yapay } \\
\text { asit yağmuru ( } \mathrm{pH} 3.4) \text { uygulaması }\end{array}$ & $\begin{array}{l}\text { Hem kombine hem de ozon işlem- } \\
\text { lerinde } 1 \text { yıllık iğne yapraklarda pero- } \\
\text { ksidaz aktivitesi, poliamin, putresin ve } \\
\text { spermidinde artış }\end{array}$ \\
\hline & $\begin{array}{l}\text { Büyüme ortamında }(3 \quad \text { yıllık } \\
\text { fidanlar })\end{array}$ & $\begin{array}{l}3 \text { ay boyunca günde } 14 \text { saat ozon (100 ppb) } \\
\text { uygulaması }\end{array}$ & $\begin{array}{l}\text { Bitkinin spesifik aktivitesinde azalma; } \\
\text { mitokondriyal aktivitede artış; kuraklık } \\
\text { stresiyle Rubisco aktivitesinde azalma }\end{array}$ \\
\hline & $\begin{array}{l}\text { Fumigasyon odalarında (2 yıllık } \\
\text { fidanlar) }\end{array}$ & $\begin{array}{l}1 \text { yıl boyunca tek başına ve kombine ozon (50 } \\
\text { ppb) ve } \mathrm{SO}_{2}(40 \mathrm{ppb}) \text { uygulaması }\end{array}$ & $\begin{array}{l}\text { Kök ve toplam biyokütlede işlemler tek } \\
\text { tek etkisiz; kombinasyonda toplam } \\
\text { biyokütlede \%25 azalma ve mikorizal } \\
\text { etki }\end{array}$ \\
\hline
\end{tabular}


Tablo 1. Bazı Akdeniz orman ağacı türlerine hava kirliliğinin etkileri (Bussotti ve Ferretti, 1998) (devam ediyor.)

\begin{tabular}{|c|c|c|c|}
\hline Tür & Deney Tipi & Kirletici/Konsantrasyon/Zaman & Etkiler \\
\hline \multirow[t]{4}{*}{$\begin{array}{l}\text { Pinus } \\
\text { halepensis }\end{array}$} & Saksılı bitkilerde işlemler & $\begin{array}{l}4 \text { farklı yapay asit yağmuru uygulaması }(\mathrm{pH} 7.5 \text {, } \\
6,4.5,3)\end{array}$ & $\begin{array}{l}\text { En asidik işlemlerde kök uzunluğunda } \\
\text { azalma, temel alt katmanda ektomikori- } \\
\text { za mantarına olumlu etki }\end{array}$ \\
\hline & Serada (3 yıllık fidanlar) & Episodik ozon fumigasyonları (100-110 ppb) & $\begin{array}{l}\text { Nitrat reduktazın depresyonu; poliamin } \\
\text { birikimi, yeni iğne yapraklarda glutatyon } \\
\text { ve askorbat; kuraklık ve hava kirliliğiyle } \\
\text { toplam fenol ve glutatyonda azalma }\end{array}$ \\
\hline & $\begin{array}{l}\text { Açık hava denemesinde (18 } \\
\text { aylık fidanlar) ve büyüme oda- } \\
\text { larında ( } 24 \text { aylık fidanlar) }\end{array}$ & $\begin{array}{l}\text { 1-2 büyüme sezonu boyunca } 5 \text { haftalık günde } 12 \\
\text { saat ozon (150 ppb) vuygulaması }\end{array}$ & $\begin{array}{l}\text { Yaygın stoma iletkenliğinde artış, } \\
\text { Nişasta içeriğinde azalma }\end{array}$ \\
\hline & $\begin{array}{l}\text { Üstü açık ortamda ( } 24 \text { aylık } \\
\text { fidanlar) }\end{array}$ & $\begin{array}{l}20 \text { aylık süre boyunca yaz işlemlerinde (haftada } \\
5 \text { gün, günde } 7 \text { saat) ozon (filtrelenmiş, ortam } \\
\text { havası }+40 \text { ppb ozon) uygulaması, kuraklık } \\
\text { işlemleri }\end{array}$ & $\begin{array}{l}\text { Ozon ve kuraklık işlemleri arasındaki } \\
\text { gaz değişim oranları üzerine antagonis- } \\
\text { tic (ters yönde) etkiler }\end{array}$ \\
\hline \multirow{2}{*}{$\begin{array}{l}\text { Pinus } \\
\text { pinaster }\end{array}$} & Serada (3 yıllık fidanlar) & $\begin{array}{l}60 \text { gün boyunca yapay asit yağmuru işlemi }(\mathrm{pH} \\
5.4,4.4,3.4,2.4)\end{array}$ & $\begin{array}{l}\text { En asidik (pH } 3.4 \text { ve } 2.4 \text { ) işlemlerde } \\
\text { epikutikular mum yapısında değişim, } \\
\text { POD aktivitelerinde etkisiz }\end{array}$ \\
\hline & $\begin{array}{l}\text { Büyüme ortamında ( } 2 \text { haftalık } \\
\text { fidanlar) }\end{array}$ & Kültür ortamında asidite (pH $3.5-6)$ uygulaması & $\begin{array}{l}\text { Düşük pH köklerin uzaması ile } \mathrm{K}, \mathrm{Ca}, \\
\text { Mg, Mn alımına etkili ama biyokütleler- } \\
\text { ine etkisiz; P, Fe ve Al alımını artırır }\end{array}$ \\
\hline $\begin{array}{l}\text { Pinus } \\
\text { pinea }\end{array}$ & Serada kaplı fidanlar & $\begin{array}{l}72 \text { saat boyunca kültür ortamında asidite }(\mathrm{pH} \\
3.5,5.5) \text { uygulaması }\end{array}$ & $\begin{array}{l}\text { En düşük pH'da kök uzamasında azal- } \\
\text { ma }\end{array}$ \\
\hline $\begin{array}{l}\text { Quercus } \\
\text { pubescens }\end{array}$ & $\begin{array}{l}\text { Fumigasyon odalarında (2 yıllık } \\
\text { fidanlar) }\end{array}$ & $\begin{array}{l}23 \text { hafta boyunca sülfür dioksit (28-61-93 ppb) } \\
\text { uygulaması }\end{array}$ & $\begin{array}{l}\text { Mezofil bozulmasıyla birlikte } Q . p u- \\
\text { bescens'in stomalarının doğası ve } Q \text {. } \\
\text { cerris'de fotosentetik sınırlama }\end{array}$ \\
\hline Q. ilex & $\begin{array}{l}\text { Büyüme ortamında (4 yıllık } \\
\text { fidanlar) }\end{array}$ & $\begin{array}{l}4 \text { gün için günde } 6 \text { saat ozon }(0,65,175,300 \\
\text { ppb) uygulaması }\end{array}$ & $\begin{array}{l}300 \text { ppb'den daha düşük işlemler fo- } \\
\text { tosentez, klorofil flüoresanı, POD ak- } \\
\text { tivitelerine etkisiz }\end{array}$ \\
\hline $\begin{array}{l}\text { Arbutus } \\
\text { unedo; } \\
\text { Viburnum } \\
\text { tinus }\end{array}$ & $\begin{array}{l}\text { Fumigasyon odalarında ( } 2 \text { yıllık } \\
\text { fidanlar) }\end{array}$ & $\begin{array}{l}80 \text { gün boyunca sülfür dioksit (25-60 ppb) uygu- } \\
\text { laması }\end{array}$ & $\begin{array}{l}\text { Arbutus unedo'da fotosentetik faaliyeti } \\
\text { azaltırken Viburnum tinus'da etkisiz }\end{array}$ \\
\hline $\begin{array}{l}\text { Hedera } \\
\text { helix }\end{array}$ & Fumigasyon odalarında & $\begin{array}{l}30 \text { gün boyunca günde } 5 \text { saat } 60 \text { ve } 200 \text { ppb } \\
\text { ozon uygulamaları }\end{array}$ & $\begin{array}{l}\text { Yüksek doz ozonda gliyoksalat ak- } \\
\text { tivitesinde azalma; her iki işlemde ise } \\
\text { kısmen stoma kapanması ve asimilatif } \\
\text { aktivitede azalma }\end{array}$ \\
\hline \multirow{3}{*}{$\begin{array}{l}\text { Eucalyptus } \\
\text { sp.pl }\end{array}$} & $\begin{array}{l}\text { Üstü açık ortamda (1 yıllık } \\
\text { fidanlar) }\end{array}$ & $\begin{array}{l}107 \text { gün boyunca günde } 4 \text { saat sülfür dioksit ( } 5 \text {, } \\
50,122,175,332 \mathrm{ppb}) \text { uygulaması }\end{array}$ & $\begin{array}{l}175 \text { ppb ve üzeri konsantrasyonlarda } \\
\text { okaliptusta büyüme azalması }\end{array}$ \\
\hline & $\begin{array}{l}\text { Üstü açık ortamda (1 yıllık } \\
\text { fidanlar) }\end{array}$ & $\begin{array}{l}169 \text { gün boyunca haftada } 3 \mathrm{kez} \text { günde } 2 \text { saat } \\
\text { azot oksit ( }>5,25,50,91,187 \mathrm{ppb}) \text { ve ayrıca } \\
\text { farklı sıklıklarla } 100 \mathrm{ppb} \text { azot oksit uygulamaları }\end{array}$ & $\begin{array}{l}\text { Türlere göre farklı etki, düşük azot oksit } \\
\text { konsantrasyonlarında büyüme artışı }\end{array}$ \\
\hline & $\begin{array}{l}\text { Üstü açık ortamda (7 aylık fi- } \\
\text { danlar) }\end{array}$ & $\begin{array}{l}18 \text { hafta boyunca iki haftada } 5 \text { gün, günde } 7 \text { saat } \\
\text { ozon (26-172 ppb) uygulaması }\end{array}$ & $\begin{array}{l}\text { Türlere göre hassasiyet farklılığı } \\
\text { (büyümede azalma ve yaprak yara- } \\
\text { lanmaları) }\end{array}$ \\
\hline $\begin{array}{l}\text { Eucalyptus } \\
\text { globulus }\end{array}$ & Saksılı bitkilerde işlemler & $\begin{array}{l}\text { Yapay asit yağmuru (8 saatte bir pH 3.5; } 4 \text { ve } 8 \\
\text { saatte bir pH 2.2) uygulaması }\end{array}$ & $\begin{array}{l}\text { Bütün işlemlerde net fotosentezde } \\
\text { azalma }\end{array}$ \\
\hline
\end{tabular}




\section{Birincil (Primer) Kirleticiler}

\section{Kükürt oksitler $\left(\mathrm{SO}_{\mathrm{x}}\right)$}

Yerel ölçekte görünür yaprak zararları (kloroz vb.), bitki büyümesinde bozulma ve ormanların azalmasına neden olurlar. Görünür bir zararı olmasa bile, $\mathrm{SO}_{2}$ büyüme ve verimde bir azalmaya neden olabilir (Emberson, 2003). Kükürtoksitler, bitkilerde vejetatif gelişmeyi etkiler, bitki yapraklarına stomalardan girer ve hücre duvarını zedeler. Yüksek $\mathrm{SO}_{2}$ konsantrasyonuna bağlı olarak, bitki hücreleri küçülür ve kloroplastlar parçalanarak yaprağın asıl renginde açılmalar olur (Elkoca, 2002). Geniş yapraklı bitkilerde damarlar arası yaprak dokusu üzerinde beyaz-saman sarısı lekelere neden olur (Müezzinoğlu, 2003). Kükürt oksitelerin neden olduğu bu olumsuz etkiler yüksek nispî nem şartlarında daha da şiddetlidir. . $\mathrm{SO}_{2}$ 'in bu zararlı etkisi özellikle yaprağı yenen bahçe bitkileri için çok önemlidir.

Kükürt oksitlerin bitkilerde protein sentezini olumsuz etkilediği de bilinmektedir. Nitekim, yapılan bir çalışmada baklagillerde yaprak ve tohumda toplam protein miktarını kontrole göre azalttığı tespit edilmiştir. Bitki gruplarında $\mathrm{SO}_{2}$ 'in etkileri üzerine Hollanda'da yapılan bir çalışmada, $\mathrm{SO}_{2}$ zararına bağlı olarak meyvelerde $\% 1.0$, açıkta sebze yetiştiriciliğinde $\% 0.9$, sera sebzeciliğinde $\% 1.8$, kesme çiçek yetiştiriciliğinde $\% 0.9$ ve saksı çiçekçiliğinde ise \%2.5 oranında verim kaybının meydana geldiği belirlenmiştir (Elkoca, 2002).

$\mathrm{SO}_{2}$ stomaların kapanmasını engellemekte ve bunun sonucunda, bitkilerin fazla miktarda su kaybederek fizyolojik kuraklıkla karşı karşıya kalmalarına neden olmaktadır (Özkan, 1988). $\mathrm{SO}_{2}$ stomalardan asimilasyon organlarına girince mezofil dokusunda bulunan kloroplastları parçalamakta ve klorofilin yapısında bulunan demir ile reaksiyona girerek klorofili ayrıştırmaktadır (Çepel ve ark., 1980).

\section{Azot oksitler $\left(\mathrm{NO}_{\mathrm{x}}\right)$}

Azot oksitler, bitki gelişimi bakımından $\mathrm{SO}_{2}$ ve ozon kadar tehlikelidir. Azot oksitler, kükürt dioksitle beraber asit yağmurlarına sebep olmak suretiyle de zarar yapmaktadırlar. Düşük azot oksit konsantrasyonlarının (0.05 ppm) etkisi altında uzun süre kalan bitkilerin büyümelerinde belirgin bir azalma olurken, bir kaç saat süreyle 2-10 ppm arasındaki konsantrasyona maruz kalmış bitkilerde şiddetli zararlar ortaya çıkmaktadır. Azot oksitler içerisinde azot dioksit, azot monoksite oranla bitki ve ağaçlara daha fazla zarar vermekte; kök gelişimi, solunum ve fotosentezde ciddi azalmalara neden olabilmektedir (Elkoca, 2002).
Azot oksitler bitki büyümesinde bozulma ve stres faktörlerine karşı hassasiyeti artırmaktadır (Emberson, 2003). Azot oksitlere maruz kalmış bitkilerde kurağa, böcek zararına ve bazı durumlarda dona karşı hassasiyet artmaktadır (CLAG, 1996). Uzun süreli azot oksite maruz kalma fotosentezi engelleyerek bitki büyümesini baskı altına alır. Azot oksitlerle diğer kirleticilerin kombinasyonu bitkiler üzerine sinerjik bir etkiye neden olmaktadır. Yani vejetasyonu daha büyük boyutta etkilemektedirler (Emberson, 2003). Honour ve ark. (2009) aşırı azot oksitin kent vejetasyonu üzerine olumsuz etkiye sahip olduğunu vurgulamışlardır.

$\mathrm{NO}_{2}$ çoğunlukla yaprak ve fidanları etkilemekte ve bitki ve dokunun yaşının artmasıyla etkisi azalmaktadır. Koniferler ilkbahar ve yaz aylarında kış aylarına kıyasla bu gaza karşı daha hassastırlar. En yaygın görünür etkiler angiosperm yapraklarındaki kloroz ve gymnosperm iğne yapraklarındaki uç yanmasıdır (Gheorghe ve Ion, 2011).

\section{Karbon gazları}

CO gazı epinasti, kloroz ve absisyona neden olur. Bununla birlikte, haftalık bu gazın 100 ppm'den daha az miktarına maruz kaldıklarında herhangi bir zarar görmezler (Gheorghe ve Ion, 2011).

\section{Partiküller}

Kirli havada yüksek miktarda bulunan partiküller kloroplastlara olan ışık transmisyonunun ve gaz değişim etkinliğinin azalmasına neden olabilir. Aynı zamanda, partikül kirliliği tomurcuk patlaması, tozlaşma ve ışık emilimi/yansıması gibi diğer fizyolojik proseslere engel olabilir. Partiküllerin bitkilerin patojen enfeksiyonuna karşı hassasiyeti arttırdığı ve genetik yapılarında uzun süreli değişimler neden olduğu da rapor edilmiştir (Emberson, 2003).

Partiküller, bitkide su dengesi ve özümleme faaliyetlerini bozmakta, gelişme bozukluklarına, verim ve kalitede azalmalara sebep olmaktadırlar. Diğer taraftan, kalabalık yerleşim alanları ve endüstri bölgelerinde, havaya yayılan tozlar içerisinde yer alan kurşun gibi çeşitli metaller bitkiler tarafından alınarak kök, gövde ve yapraklarda depolanmaktadır. Bunun sonucunda başta fotosentez olmak üzere pek çok fizyolojik olay olumsuz yönde etkilenmekte ayrıca, köklerde biriken metaller baklagillerde nodülasyonu engellemek suretiyle bağlanan azot miktarında önemli azalmalara neden olmaktadır (Singh ve ark., 1997). 


\section{İkincil (Sekonder) Kirleticiler}

\section{Ozon $\left(\mathrm{O}_{3}\right)$}

Ozona hassasiyet bakımından bitki türleri arasında geniş bir varyasyon görülmektedir. Yüksek ozon konsantrasyonları yaprağın deforme olmasına ve tipik olarak üst yüzeyde beyazımsı lekelerin oluşmasına neden olmaktadır (Müezzinoğlu, 2003). Bölgesel ölçekte, görünür yaprak zararları, büyümede azalma ve ormanların azalmasına neden olur (Emberson, 2003). Geniş yapraklı bitkilerde kloroz, beyazlaşma, bronzlaşma, lekelenme, beneklenme ile tek ve iki yüzlü nekroz gibi net belirtiler görülür. Koniferlerde uç nekrozu, lekelenme ve beneklenme en yaygın belirtilerdir (Kley ve ark., 1999).

Ozona $\left(\mathrm{O}_{3}\right)$ duyarlı türler, yüksek gaz değişim kapasitesi ve dolayısıyla yüksek ozon alımı ile ilişkilendirilen düşük yaprak yoğunluğu ile karakterizedir (Gravano ve ark., 2003). Diğer taraftan, buğday da ozona hassasiyet göstermekte; ozon, buğday bitkisinde özellikle bayrak yapraktaki hücrelerde yapısal bozukluklara sebep olmak, bayrak yaprak süresini kısaltmak ve bayrak yaprakta üretilen asimilatların başağa transferini kısıtlamak suretiyle tohum verimini olumsuz yönde etkilemektedir (Pleijel ve ark., 1998).

Yüksek miktarda ozon kirliliğinin Pinus ponderosa iğne yapraklarında kloroz ve erken yaşlanmaya neden olduğu belirlenmiştir (Miller ve McBride, 1999). Ozon ladin, göknar ve kayın ağaçlarının taç yaprak dökümünü etkilemektedir (Zierl, 2002). Ozolincius ve Serafinaviciute (2003), ozona maruz kalan dişbudak ağaçlarında yaprak dökümünün arttığını, sağlıklı ağaç oranının ise azaldığını ortaya koymuşlardır. Hindistan'ın Varanasi şehrinde yürütülen bir çalışmada, ozonun kırsal alanda daha etkili olduğu görülmüş ve hava kirliliğinin ürün verimini olumsuz yönde etkileyebileceği sonucuna varılmıştır (Agrawal ve ark., 2003).

\section{Asit yağmurları}

Asit yağmurları yaprakların stomalarından girerek yaprağın su dengesini sağlayan stoplazmanın asitleşmesine neden olurlar. Ağaçlar ve ıspanak gibi yaprağı yenilen sebzelerde $\mathrm{SO}_{2}$, yaprak yüzeyini bir katman halinde kapatır ve fotosentez faaliyetini engeller. Bunun sonucunda su kaybeden yaprak kısa sürede ölür. Ayrıca zamanla zayıflayan ve yaprak kaybeden ağacın üst kısımları seyrekleşerek rüzgâr perdesi görevini yapamaz ve ağaç rüzgârdan devrilebilir. Böylece ağaçların yeşil sürgünleri gelişmeyip kurumakta, yaprakları dökülmekte, çiçek ve meyve vermemektedir (Kant ve Kızıloğlu, 2003).
Toprağa ulaşan asit yağmurları toprak asitliğine yol açmaktadır. Bu tip asit topraklarda, toprak minerallerindeki alüminyum ve manganez iyonları çözünerek köklere toksik etki yapmaktadır (Esher ve ark., 1992).

\section{Peroksi Asetil Nitrat (PAN)}

En yaygın görünür belirtileri yapraklarda kloroz ve nekroz oluşumudur. Aynı zamanda bitkilerde fotosentez ve solunum ile karbonhidratların ve proteinlerin emilimini ve sentezini engellemektedir (Gheorghe ve lon, 2011). Ozonda olduğu gibi PAN zararına uğramış bitkilerde de erken yaprak yaşlanması ve buna bağlı olarak yaprak dökümü meydana gelmektedir.

Diğer taraftan, fotooksidant olması nedeniyle yüksek ışık yoğunluğunda PAN zararı artış göstermekte ve bitkide solunumu teşvik etmek suretiyle net fotosentezde kayıplara neden olmaktadır. Marul ve soya fasulyesinde 0.01-0.05 ppm gibi düşük PAN konsantrasyonlarında dahi bazı belirtiler ortaya çıkarken, kabak, mısır ve buğday aynı konsantrasyonlardan zarar görmemektedir (Hatipoğlu ve ark., 1988).

\section{Ağır metaller}

Bazı ağır metaller düşük dozlarda bitkiler için önemli mikro-elementlerdir. Fakat yüksek dozlar bitki türlerinin çoğunun büyümesini engeller ve metabolik düzensizliğe sebep olabilir. Ağır metaller bitki dokularında aşırı biriktiği zaman mineral beslenme, transpirasyon, fotosentez, enzim aktivitesi, nükleik asit yapısı, klorofil sentezi ve çimlenme olumsuz yönde etkilenir. Bunlara ek olarak membranlarda hasar, hormon dengesinin bozulması ve su iliş̧isinin değişmesi gibi durumlar da görülebilmektedir (Okcu ve ark., 2009).

Ağır metal etkisinde bitkilerin kök ve sürgün büyümesi azalır, kökler incelir, genç yapraklar kıvrılır ve kloroz görülür, hücre büyümesi ve uzaması engellenir, hücre organelleri parçalanır ve klorofil sentezi azalır. Artan çinko konsantrasyonları mitoz bölünmeyi engeller, ayrıca hücrelerin ligninleşmesini sağlayarak hem kök hem de gövde büyümesini engeller (Asri ve Sönmez, 2006).

Ağır metaller, hücre turgoru ve hücre duvarı stabilitesini olumsuz etkilemesi, stoma hareketlerini ve yaprak alanını azaltması nedeniyle bitki su rejimini etkilemektedir. Aynı zamanda kökler tarafından tutulması ve kök gelişimini azaltması nedeniyle bitkilerin katyon ve anyon alımını azaltmakta dolayısıyla besin alımını etkilemektedir (Asri ve Sönmez, 2006).

Civa, çinko, nikel, kobalt, kurşun ve kadmiyum gibi ağır metal iyonları elmada polen çimlenmesini ve polen tüpü uzamasını engellemektedir. Ağır metaller arasında en 
fazla toksik etkiyi civa göstermektedir (Munzuroğlu ve Gür, 2000).

\section{SONUÇLAR VE ÖNERILER}

Bitkiler hareketsiz olduğu ve fizyolojik tepki bakımından hava kirliliğine karşı insanlar ve hayvanlardan daha hassas olduğu için, yerel koşulları daha iyi yansıtmaktadırlar. Bitki yaprakları hava kirliliğine uzun süreli düşük konsantrasyonlarda bile maruz kalsa görünür yaralanmalar olmaksızın bitki yapraklarında zararlı etkiler görülmektedir. Hava kirliliğinin bitkiler üzerindeki bu zararlı etkilerini azaltmak amacıyla aşağıda belirtilen önlemler alınabilir:

- Hava kirliliğine neden olan tesisler $\mathrm{SO}_{2}, \mathrm{NO}_{\mathrm{x}}$ ve diğer hava kirletici gazları arıtmak amacıyla ileri arıtım teknolojisine sahip olmalıdır.

- Alternatif enerji kaynaklarına öncelik verilmelidir.

- Toplu taşımanın daha yaygın kullanımı konusunda toplum bilinçlendirilmeli ve özendirilmelidir.

- Hava kirliliği ile ilgili yasal düzenlemeler revize edilmeli ve daha da önemlisi yaptırımlar caydırıcı olmalıdır.

- Bitki ıslah programları çerçevesinde hava kirleticilere karşı daha toleranslı ırklar tespit edilmeli ve Islah edilmelidir.

\section{KAYNAKLAR}

Agrawal, M., Singh, B., Rajput, M., Marshall, F., Bell, J.N.B. (2003). Effect of Air Pollution on Peri-Urban Agriculture: A Case Study. Environmental Pollution, 126: 323-329.

Amil, M. (2005). Ankara Hava Kalitesinin Alansal ve Zamansal Değişiminin İncelenmesi. Atatürk Üniversitesi Fen Bilimleri Enstitüsü, Yüksek Lisans Tezi, Erzurum.

Ashmore, M.R., Marshall, F.M. (1999). Ozone Impacts on Agriculture: An Issue of Global Concern. Advances in Botanical Research, 29: 32- 49.

Asri, F., Sönmez, S. (2006). Ağır Metal Toksisitesinin Bitki Metabolizması Üzerine Etkileri. Derim Dergisi, 2(23): 3645.

Bayram, H. (2005). Türkiye'de Hava Kirliliği Sorunu: Nedenleri, Alınan Önlemler ve Mevcut Durum. Toraks Dergisi, 6(2): 159-165.

Bayram, H., Dörtbudak, Z., Fişekçi, F.E., Kargın, M., Bülbül, B. (2006). Hava Kirliliğinin Insan Sağlığına Etkileri, Dünyada, Ülkemizde ve Bölgemizde Hava Kirliliği Sorunu. Dicle Tıp Dergisi, 33(2): 105-112.

Bussotti, F., Ferretti, M. (1998). Air Pollution, Forest Condition and Forest Decline in Southern Europe: an Overview. Environmental Pollution, 101 (1): 49-65.

CLAG, (1996). Critical Levels of Air Pollutants for the United Kingdom. Critical Loads Advisory Group, Institute of Terrestrial Ecology, Penicuik.

Çepel, N., Dündar, M., Ertan, E. (1980). Samsun-Gelemen Orman Fidanlığında Görülen Duman Zararları Üzerine Araştırmalar. İstanbul Üniversitesi Orman Fakültesi Dergisi, 30: 6-42.
Çınar, Ö. (2008). Çevre Kirliliği ve Kontrolü. Nobel Yanıcılık, Ankara.

Demirel, E. (2010). Erzurum Kent Atmosferindeki Polislik Aromatik Hidrokarbonların (PAH) Örneklenmesi ve Analizi. Atatürk Üniversitesi Fen Bilimleri Enstitüsü, Yüksek Lisans Tezi, Erzurum.

Dursun, A., Aslantaş, R., Pırlak, L. (1998). Hava Kirliliğinin Bahçe Bitkileri Yetiştiriciliği Üzerine Etkileri. ÇEVKOR, 7(27): 11-14.

Eğri, M. (1997). 1996-1997 Kış Döneminde Malatya III Merkezi Hava Kirliliği Parametrelerine Meteorolojik Koşulların Etkisi. Turgut Özal Tıp Merkezi Dergisi, 4(3): 265-269.

Elkoca, E. (2002). Hava Kirliliği ve Bitkiler Üzerindeki Etkileri. Atatürk Üniversitesi Ziraat Fakültesi Dergisi, 34(4): 367374.

Emberson, L.D. (2003). Air pollution impacts on crops and forests: an introduction. Ashmore, M.R., Emberson, L.D., Murray, F.M. (eds.) Air Pollution impacts on crops and forests: A Global Assessment, Imperial College Press. London, Bölüm 1, 3-29.

Esher, R.J., Marx, D.H., Ursic, S.J., Baker, R.L., Brown, L.R., Coleman, D.C. (1992). Simulated Acid Rain Effects on Fine Roots, Ectomycorrhizae, Micro-Organisms, and Invertebrates in Pine Forests of The Southern United States. Water, Air and Soil Pollution, 61: 269-278.

Ganatas, P., Tsakaldimi, M., Zachariadis, G. (2011). Effect of Air Traffic Pollution on Seed Quality Characteristics of Pinus brutia. Environmental and Experimental Botany, 74: 157-161.

Gheorghe, I.F., Ion, B. (2011). The Effects of Air Pollutants on Vegetation andthe Role of Vegetation in Reducing Atmospheric Pollution. The Impact of Air Pollution on Health, Economy, Environment and Agricultural Sources", kitabı, editör: Mohamed K. Khalla, Bölüm 12, DOI: 10.5772/17660.

Govindaraju. M., Ganeshkumar. R.S., Suganthi. P., Muthukumaran. V.R, Visvanathan. P. (2010). Impact Assessment of Air Pollution Stress on Plant Species through Biochemical Estimations. World Academy of Science, Engineering and Technology, 48: 933-936.

Gravano, E., Giulietti, V., Desotgiu, R., Bussotti, F., Grossoni, P., Gerosa, G., Tani, C. (2003). Foliar Responses of an Ailanthus Altissima Clone in Two Sites with Different Levels of Ozone-Pollution. Environmental Pollution, 121: 137-146.

Hatipoğlu, R., Tükel, T., Koç, M. (1988). Çevre Kirlenmesinin Bitkiler Üzerindeki Etkileri. Çukurova Üniversitesi Ziraat Fakültesi Dergisi, 2(3): 119-133.

Heck, W.W., Taylor, O.C., Tingey, D.T. (1988). Assessment of Crop Loss from Air Pollutants", Elsevier Applied Science, London.

Honour, S.L. Bell, J.N.B. Ashenden, T.A. Cape, J.N., Power, S.A. (2009). Responses of herbaceous plants to urban air pollution: Effects on growth, phenology and leaf surface characteristics. Environmental Pollution, 157(4): 12791286.

Kant, C., Kızıloğlu, T. (2003). Asit Yağmurlarının Canlılar Üzerine Etkileri. Atatürk Üniversitesi Ziraat Fakültesi Dergisi, 2(34): 217-221.

Kantarcı, D. (1995). Hava Kirliliğinin Bitkiler Üzerine Doğrudan ve Dolaylı Etkileri. http://www.mmo.org.tr/resimler/dosya_ekler/6ef5f7fa914c 199_ek.pdf?dergi $=169$ 
Karnosky, D., Witter, J., Gagnon, Z., Reed, D. (1992). Effects of Genotype on The Response of Populus-Tremuloides Michx to Ozone and Nitrogen Deposition. Water Air and Soil Pollution, 62(3-4): 189-199.

Kley, D., Kleinmann, M., Sanderman, H., Krupa, S. (1999). Photochemical oxidants; state of the science. Env. Pollut. 100: 19-42.

Longauer, R., Gömöry, D., Paule, L., Blada I., Popescu, F., Mankovska, B., Müller-Starck, G., Schubert, R., Percy, K., Szaro, R.C., Karnosky, D.F. (2004). Genetic Effects of Air Pollution on Forest Tree Species of The Carpathian Mountains. Environmental Pollution, 139: 85-92.

Miller P.R., McBride, J. (1999). Oxidant Air Pollution Impacts in the Montane Forests of Southern California: The San Bernadino Mountain Case Study. Springer-Verlag, New York.

Munzuroğlu, Ö., Gür, N. (2000). Ağır Metallerin Elma (Malus sylvestris Miller cv. Golden)'da Polen Çimlenmesi ve Polen Tüpü Gelişimi Üzerine Etkileri. Türk Biyoloji Dergisi, 24: 677-684.

Müezzinoğlu, A. (2003). Hava Kirliliği ve Kontrolünün Esasları. Dokuz Eylül Yayınları, İzmir.

Nuhoğlu, Y. (2005). The harmful effects of air pollutants around the Yenikoy thermal power plant on architecture of Calabrian pine (Pinus brutia Ten.) needles. Journal of Environmental Biology 26 (2): 315-322.

Okcu, M., Tozlu, E., Kumlay, A.M., Pehluvan, M. (2009). Ağır Metallerin Bitkiler Üzerine Etkileri. Alınteri Dergisi, 17: 1426.

Ozolincius, R., Serafinaviciute, B. (2003). Ozone-Induced Visible Foliar Injuries in Lithuania. Baltic Forestry, 9(2): 51-57.

Özkan, N. (1988). Asit Yağmurları ve Orman Tahribatı. Orman Mühendisliği Dergisi, 2(25): s.22-25.
Pandey, J., Agrawal, M. (1994). Growth-responses of Tomato Plants to Low Concentrations of Sulfur Dioxide and Nitrogen Dioxide. Scientia Horticulturae, 58(1-2): 67-76.

Pleijel, H., Danielsson, H., Gelang, J., Sild, E., Sellden, G. (1998). Growth Stage Dependence of The Grain Yield Response to Ozone in Spring Wheat (Triticum aestivum L.). Agriculture, Ecosystems and Environment, 1(70): 6168.

Seyyednejad, S.M., Koochak, H. (2011). A Study on Air Pollution Effects on Eucalyptus Camaldulensis. International Conference on Environmental, Biomedical and Biotechnology, 16: 98-100.

Singh, R.P., Tripathi, R.D., Sinha, S.K., Maheshwari, R., Srivastava, H.S. (1997). Response of Higher Plants to Lead Cantamined Environment. Chemosphere, 11(34): 24672493.

Tolunay, D. (2003). Air pollution effects on annual ring widths of forest trees in mountainous land of İzmir (Turkey). Water, Air, and Soil Pollution: Focus 3: 227-242.

Tolunay, D., Öztürk, S., Karakaş, A., Akkaş, M., Adıgüzel, U., Gürlevik, N., Taşdemir, C., Aytar, F. (2013). Türkiye'de Hava Kirliliğinin Ormanlar Üzerindeki Etkilerinin İzlenmesi ve Değerlendirilmesi Uluslararası İşbirliği Programı (Icp Forests)'ndan Elde Edilen Sonuçlar. Hava Kirliliği ve Kontrolü Sempozyumu, Bildiriler Kitabı, 6-21

URL1 (2015). www.mevzuat.gov.tr

Zierl, B. (2002). Relations Between Crown Condition And Ozone And Its Dependence on Environmental Factors. Environmental Pollution, 119: 55-68.

Wahid, A., Maggs, R., Shamsi, S.R.A., Bell, J.N.B., Ashmore, M.R. (1995). Air Pollution and its impacts on Wheat Yields in the Pakistan Punjab. Environmental Pollution, 88: 147154. 